neglect to direct attention to the dangers attending the surgical use of diathermy apparatus in the presence of ether vapour. The thanks of all workers in the field of radiology throughout the world are due to the British X-Ray and Radium Protection Ccmmittee for its pioneer and continuing labours in this field.

\section{Vitamin C Content of Oranges}

IN the issue of the New England Journal of Medicine of January 7, Dr. Arthur D. Holmes, James A. Patch and Francis Tripp of the Research Laboratories of E. L. Patch Co., Stoneham, Mass., record their observations on the relation of season, weight and price to the vitamin $\mathrm{C}$ content of oranges. They found that there was considerable seasonal influence on nutritive value, the oranges being heavier and containing more juice at a lower vitamin $\mathrm{C}$ cost in December than at any other seasons, of the year. The cost of $75 \mathrm{mgm}$. was 4.8 cents in March, 5.9 cents in June and September and $3 \cdot 6$ cents in December. The average purchaser, therefore, cannot use the size or cost of oranges as a reliable guide to the amount of juice or to the cost of the daily requirements of vitamin $\mathrm{C}$.

\section{New Zealand Earthquakes}

DURING March 1943, fifteen strong earthquakes were registered by the seismographs at Auckland, Arapuni, Bunnythorpe, Christchurch, Kaimata, New Plymouth, Tuai and Wellington, all stations participating in the New Zealand Seismolrgical Service and sending records or readings to the Dominion Observatory at Wellington (New Zealand Seismological Report-Provisional Bulletin, No. P 133, 1943, March). The records are remarkable in that eight of the shocks had a depth of focus greater than normal. The first, on March 4, had an epicentre south of Fiji and a depth of focus near $600 \mathrm{~km}$. The shock of March 11 with epicentre east of New Caledonia had a depth of focus near $100 \mathrm{~km}$. Earthquakes on March 15 and 21 have already been reported in Nature, the data coming from the U.S. Coast and Geodetic Survey. On March 26 a very strong earthquake with an epicentre south-east cf Tonga had a focal depth of between 80 and $100 \mathrm{~km}$. It was reported to have been felt at Nukualofs, according to a message from Apia. The earthquake gave very large amplitudes on the vertical ccmponents of seismographs. Further, there was minor seismic activity, and 22 earthquakes or earth tremors were reported as having been felt (additionally) in $\mathrm{N} \in \mathrm{w}$ Zealand. The greatest of these shocks was Scale VI on the Modified Mercalli Scale. It occurred on March 14 and was felt in the southern part of South Island. Two earthquakes were felt with Scale V intensity. The first, on March 1, was felt from Te Kuiti and Waipawa to Greymouth and Rakaia. 'The second, on March 25, was felt at Westport. One shcck was felt with Scale IV intensity and the rest with lesser intensities.

\section{Earth Tremors in Portugal}

EARTH tremors accompanied by earthquake noises were reported from Oporto, Braga and Viana do Costelo in north Portugal to have taken place on the night of June 22. Although these tremors caused some apprehension, they did not last long and no serious damage has been reported.

\section{Centenary of the S.S. Great Britain}

ON July 19, 1843, in the presence of the Prince Consort, the famous Great Britain was floated in the dock at Bristol in which she had been under construction for four years. As the first iron ship built for the Atlantic traffic, as the first ocean-going screw ship, and as by far the largest iron ship built up to that time, she stands out as a magnificent specimen of the art of shipbuilding as carried out by farsighted, energetic and unprejudiced men. She was $322 \mathrm{ft}$. long, $50 \frac{1}{2} \mathrm{ft}$. wide and at a draught of $18 \mathrm{ft}$. had a displacement of 3,618 tons. The credit for her construction belongs to Captain Christopher C'laxton, R.N., secretary of the Great Western Steamship Co., the famous engineer I. K. Brunel, William Patterson, a Bristol shipbuilder, and Henry Richard Guppy, another Bristolian who afterwards did good engineering work in Italy. When completed in 1845, the Great Britain, after being visited by Queen Victoria, took her place beside the Great Western on the Atlantic and made several crossings. Unfortunately, in September 1846 she ran ashore in Dundrum Bay, Co. Down, but was salved a year later. She was refitted as an auxiliary screw ship, and for many years employed on the Australian run. In 1882 she was converted into a sailing ship. Her active service came to an end four years later, when after a severe buffeting off Cape Horn she put into Port Stanley, Falkland Islands, where she became a wool hulk. Up to 1938 at least, she was still so used, an eloquent testimony to the quality of her iron hull and the workmanship of the Bristol shipbuilders.

National Research Council, Canada : Scholarships

The National Research Council, Canada, announces the award for the academic year 1943-44 of 14 fellow. ships of the value of 750 dollars each, 30 studentships of 650 dollars each and 21 bursaries of 250 dollars each. The sixty-five successful candidates for these post-graduate scholarships comprise graduates of fifteen Canadian universities, and they will carry out research work in the ecming year at eleven of these institutions. As a result of war conditions, the fields of science in which the scholarship holders will work are reduced in number as compared with a few years ago. By far the greatest number will work in various branches of chemistry related to the war effort. According to a general classification adopted in announcing the awards, 49 will study chemistry, 6 physics (including one radiology), 4 biochemistry, 2 genetics, and one each biology, mineralogy, mechanical engineering and electrical engineering.

\section{Announcements}

THE following have been elected officers and members of council of the Institution of Electrical Engineers for the year 1943-44: President: Sir A. Stanley Angwin; Vice-Presidents: Mr. T. G. N. Haldane, Dr. E. B. Moullin; Hon. Treasurer: Mr. E. S. Byng; Ordinary Members of Council: Brigadier F. T. Chapman, Mr. J. Hacking, Mr. A. L. Lunn, Dr. J. L. Miller, Mr. J. S. Forrest, Mr. E. C. S. Megaw, and Mr. E. Leete.

WE have received a copy of the revised pamphlet "Photography as an Aid to Scientific Work" from Ilford Ltd., Ilford, London. This gives lists of plates, films and papers suitable for all branches of scientific work, including medicine and surgery, clinical photography and radiography. There are also notes on filters and darkroom safe-lights. 